\title{
Negative Russian Pronoun Что
}

\author{
Irina V. Trufanova \\ State Budgetary Educational Institution of the Moscow city "School No. 224", \\ 30, Leningradskoye Shosse, Moscow, 125212, Russian Federation \\ illokucia1@rambler.ru
}

\begin{abstract}
For the first time in linguistics, the article distinguishes negative pronouns of a pronoun-noun and pronoun-adjective. Their lexical meanings, grammatical features and syntactic functions are determined. A negative pronoun is a noun that means 'nothing' (in Russian both ничто and ничего), a negative Russian pronoun что meaning 'whatever, none'. Both pronouns function as the principle sentence component, mainly in negative genitive sentences or as a predicate in a two-memberSubject-Predicate sentence. Subject of a pronoun-noun, which is expressed by the noun of any lexico-grammatical category or infinitive, with a negative pronounadjective, which is an infinitive. Both negative pronouns function in rhetorical questions expressing negation in the affirmative form. Subject combined with a pronoun-noun could be expressed by a noun of any lexico-grammatical category or infinitive, with a negative pronounadjective $ч m o$, which could also be formed by an infinitive. Both negative pronouns function in rhetorical questions expressing negation in the affirmative form. The meanings of both negative pronouns are syntactically limited (by the function of the predicate or the principle component of the negative genitive sentence) and structurally determined (be found in the construction with the dative of the authorizer). The meaning of a negative pronoun-adjective is also phraseologically confined, a negative pronoun is an adjective that is always used with the Russian words like прокy, толку, выгоды, пользы, прибыли, добра. Three meanings stand out for a negative pronoun ничто: 1) ontological vacuum, nonexistence, absence of an object; 2) something insignificant, insignificant, not worthy of attention; 3) denial of the significance of a person, insignificance. A negative pronoun umo is a noun that means 'something insignificant, insignificant, not worthy of attention' (or '(as it were) the absence of something/someone (for the authorizer)'), or 'absence (of benefit)'. A negative pronoun чmo is an adjective that has one of the meanings of a negative pronoun-adjective никакой meaning 'none of the available or possible'. Despite the indeclinability, a negative pronoun чmo expresses the noun-meanings of the nominative and genitive cases, while being a negative pronoun-adjective to denote the genitive case, either masculine or feminine. The data collected is retrieved from the National Corps of the Russian Language (NCRL). As the main methodological technique, the substitution method was applied. The theoretical basis of the article was the work on homocomplexes, functional homonyms, polyfunctional words, the differentiation of homonymy and polysemy. The theoretical significance of the study lies in the fact that the results allow us expand the linguistic understanding of the semantic and grammatical nature of the pronoun as well as the issue of pronoun syncretism in
\end{abstract}

(С) Труфанова И.В., 2020

This work is licensed under a Creative Commons Attribution 4.0 International License https://creativecommons.org/licenses/by/4.0/ 
general, the differentiation of homonymy and polysemy of the classes of pronouns, as well as the varieties of genitive sentences. The data collected can be useful for lexicographic practice: compiling dictionaries of homonyms, grammatical homonyms, explanatory dictionaries, as well as to clarify the typology of one-member sentences. The relevance of the topic is determined by the necessity to establish the full list of pronouns in the Russian language, as well as the importance of studying the phenomena of functional homonymy, transition and syncretism and the importance of solving the problem of distinguishing homonymy and polysemy.

Keywords: pronoun чmo, negative pronouns, interrogative pronouns, genitive sentences, modal meanings, homocomplex, syncretism, functional homonyms

\title{
Article history:
}

Received: 25.08 .2020

Accepted: 15.09 .2020

\section{For citation:}

Trufanova I.V. (2020). Negative Russian Pronoun Ymo. RUDN Journal of Language Studies, Semiotics and Semantics, 11 (4), 625-658. doi: 10.22363/2313-2299-2020-11-4-625-658

УдК: 81'367.626

\section{Отрицательное местоимение что}

\author{
И.В. Труфанова \\ Государственное бюджетное общеобразовательное учреждение города Москвы \\ «Школа № 224», \\ 125212, Российская Федерация, Москва, Ленинградское шоссе, 30 \\ illokucia1@ rambler.ru
}

В статье впервые в лингвистике выделяются отрицательные местоимения что, местоимение-существительное и местоимение-прилагательное. Установлены их лексические значения, грамматические признаки и синтаксические функции. Отрицательное местоимениесуществительное что имеет значение «ничто» («ничего»), отрицательное местоимениеприлагательное что - «никакого(ой)». Оба местоимения выполняют функцию главного члена предложения в отрицательных генитивных предложениях или функцию сказуемого в двусоставном предложении. Подлежащее при местоимении-существительном что выражается существительным любого лексико-грамматического разряда или инфинитивом, при отрицательном местоимении-прилагательном что - инфинитивом. Оба отрицательных местоимения функционируют в риторических вопросах, выражающих отрицание в утвердительной форме. Значения обоих отрицательных местоимений что синтаксически ограниченные (функцией сказуемого или главного члена отрицательного генитивного предложения) и конструктивно обусловленные (обнаруживаются в конструкции с дательным авторизатора). Значение отрицательного местоимения-прилагательного что еще и фразеологически связанное, отрицательное местоимение-прилагательное что всегда употребляется со словами проку, толку, выгоды, пользы, прибыли, добра. У отрицательного местоимения ничто выделяют три значения 1) онтологический вакуум, небытие, отсутствие предмета, 2) нечто незначительное, несущественное, не заслуживающее внимания, 3) отрицание значимости какого-либо лица, ничтожество. Отрицательное местоимениесуществительное что имеет значение «нечто незначительное, несущественное, не заслуживающее внимания» (или «(как бы) отсутствие чего-/кого-либо (для авторизатора)»), или «отсутствие (пользы)». Отрицательное местоимение-прилагательное что имеет одно из 
значений отрицательного местоимения никакой: «ни один из имеющихся или возможных». Несмотря на несклоняемость, отрицательное местоимение-существительное что выражает значения именительного и родительного падежей, отрицательное местоимениеприлагательное что - значение родительного падежа, мужского или женского рода. Материал собран на базе Национального корпуса русского языка. В качестве основного методического приема использовался метод подстановки. Теоретической базой статьи стали работы по омокомплексам, функциональным омонимам, полифункциональным словам, разграничению омонимии и полисемии. Теоретическая значимость исследования заключается в том, что полученные результаты позволяют расширить лингвистические представления о семантико-грамматической природе местоимения что и о проблеме местоименного синкретизма в целом, о разграничении омонимии и полисемии в классе местоимений, а также о разновидностях генитивных предложений. Собранный материал может быть полезным для лексикографической практики: составления словарей омонимов, грамматических омонимов, толковых словарей, а также для уточнения типологии односоставных предложений. Актуальность темы определяется необходимостью установления полного состава (списка) местоимений в русском языке, а также значимостью исследования явлений функциональной омонимии, переходности и синкретизма и важностью решения вопроса о разграничении омонимии и полисемии.

Ключевые слова: местоимение что, отрицательные местоимения, вопросительные местоимения, генитивные предложения, модусные значения падежей, омокомплекс, синкретизм, функциональные омонимы

\section{История статьи:}

Дата поступления: 25.08.2020

Дата приема в печать: 15.09 .2020

\section{Для цитирования:}

Труфанова И.В. Отрицательное местоимение что // Вестник Российского университета дружбы народов. Серия: Теория языка. Семиотика. Семантика. 2020. Т. 11. nо 4. С. 625658. doi: 10.22363/2313-2299-2020-11-4-625-658

\section{Introduction}

The main target of the article is to prove the existence of both the negative pronoun-noun что bearing the meaning of 'ничто/ничего' — English: 'nothing/none' and the negative pronoun-adjective umo signifying 'никакого/никакой' - English 'none/neither/not any...' in the Russian language. The tasks are the following: to describe lexical meaning, grammatical features and syntactical functions of чmo as Russian interrogative pronouns and determine whether they make up the set of meanings of the polysemic interrogative pronoun umo or they are its homonyms, or both.

The relevance of the research is determined by the necessity to make up and prove the complete set (list) of Russian pronouns as well as to elaborate the criteria to discriminate homonymy and polysemy of the pronoun class, to prove the importance of functional homonymy, transitivity and syncretism.

There exist much greater number of Russian pronouns rather than stated in school and university manuals, and linguistic studies. In our opinion, it's principally urgent to start from the the postulate stated by M.I. Otkupschikova, 
"The main means to form pronouns is to create homonymous meanings (...). One of the typical means to enlarge the pronoun classes is homonymy having the global character denoting the homonymy typical not for some pronouns, but for the classes, e.g., such as interrogative and relative pronouns, and K-quantifier pronouns" [1. P. 81].

The question is whether in Russian interrogative and negative umo are different words or different meanings of a polysemic word? At present, the criteria to distinguish homonyms and meanings of polysemic words coincide at large, and the issue to discriminate homonymy and polysemy still needs a solution [2. P. 112$113 ; 3$. P. 42; 4; 5]. There are some common criteria: 1) discrimination of the category meaning of a class of pronouns - by form or by their correlations with other parts of speech; 2) discrimination of morphological categories and the formal volume of their paradigms; 3) discrimination of their morphemic sets; 4) the existence of word-building nests; 5) variety of combinability with the units of other word classes *(morphological, lexical, syntactic), various volumes of lexical distribution, various sets of syntactical valence; discrimination of synonyms and antonyms; 6) various translations into foreign languages; 7) different stylistic qualification; 8) combinations with intonation of different kinds; 9) different structural and semantic sentence types as the environment of a word used. The only one criterion doesn't repeat: in polysemy, the word meanings are immediately or non-immediately interconnected within derivational relations, i.e., the relations of typical semantic derivations of this or that language [3. P. 79]. Generic character, frequency, not unique link between two meanings supports polysemy, and vis versa, singleness, onliness and uniqueness indicates homonymy [6. P. 209]. Principally, polysemy is quite regular, while homonyms reveal semantically independent meanings [6. P. 193]. It's quite a realistic target to demonstrate differences between the Russian interrogative pronoun-noun ymo and the negative pronoun-noun umo.

At first glance, it seems easier to discriminate a negative pronoun-adjective as thise are the words of various classes but in form and correlations with the other parts of speech. Linguistic sources used to treat this issue in connection with developing the notions of "homocomplex", "functional homonyms", "polyfunctional words", and synchronic processes of transition of the parts of speech system [see a short survey of synchronic transitivity theory developments: 6]. On te other hand, in explanatory dictionaries, homocomplexes (the tern was introduced by O.S. Akhmanova [2. P. 160-161], and widely spread in linguistics thanks to the studies of V.V. Babaytseva and her followers [8-20]) are understood as polysemic words. One of the consequences of continuous transitional processes within the Russian grammatical structure is considered to be the appearance of functional homonyms - that is, "etymologically cognate words coinciding in sound form, but belonging to different parts of speech" [21. P. 194] — and syncretic entities combining the properties of different parts of speech. The total of functional homonyms and syncretic entities combining the properties of different parts of speech are forming the term "homocomplex" [21. P. 195]. Intermediate units to appear at this are names "hybrid words" (the 
term of V.V. Vinogradov), or "contaminants" (the term of E.N. Sodorenko $[22 ; 23])$. Syncretism is understood as a universal feature of language revealing the ability of a linguistic unit to express the complex of contrasting lexical and/or grammatical meanings [11. P. 8]. Syncretism is also understood as a usual, natural, universal feature of separate units of the linguistic system as a whole [7. P. 28]. But as it appears, it's not so easy to denote the status of the Russian pronoun-adjective чmo. According to M.A. Sternina, "The acquisition of a new part of speech seme through a new separate word meaning couldn't automatically lead to the disruption of the word identity and the formation of homonyms. On the content plane, the main feature of homonyms/ in our opinion, stays the absence of derivational meanings (...). The existence of semantic connection among the meanings we have the evidence of a polysemic word, but the absence of such connections reveals homonymy" [24. P. 7]. We share another point of view as the majority of linguists does, considering functional homonyms to be different words on the basis of their belonging to different parts of speech $[9 ; 10$. P. 7; 12. P. 7; 25. P. 25; 26. P. 6].

In dictionaries, adverbs чmo, pronouns чmo (interrogative, attributive, relative, indefinite, on the one hand, pronoun-noun, and on the other hand, pronoun-numeral, pronoun-adjective) are represented as the meanings of one and the same dictionary entry. It means that the word of different meanings could belong to different parts of speech, e.g., Что принёс? — a pronoun; Что так поздно пришёл? - an adverb of reasoning; Что вы приезжали? — an adverb of targeting [27; 28. P. 27-29; 29. P. 817; 30. P. 380; 31. P. 78-81]) or different lexico-grammatical classes (Что лежит на окне? — an interrogative pronounnoun; Узнай, что он ответил. - a relative pronoun-noun; Спой песню, что певала мама. - a relative pronoun-adjective with some features of a pronounnoun [32. Р. 60]. Узнаещь что, сообщай незамедлительно. - an indefinite pronoun-noun; Что просишь за эти бусыл — an interrogative pronounnumeral; Что есть духу, давай стрекача. - a relative pronoun-numeral. D.N. Ushakov discusses the disjunctive pronoun чmo meaning 'one - another': «Что забыл, а чего и не знал никогда. Очень уж он неаккуратен: что nерепутает, что потеряет, о чем забудет» [33]. It would be more reasonable to qualify it as an attributive pronoun-noun [see.: T.F. Yefremova [34] due to the meaning 'many/much': Что здесь народу! Что в этом году водьı!]).

Interrogative pronouns are the derivational base for relative, negative and indefinite pronouns. Negative and indefinite pronouns are formed from those not only by means of prefixes and postfixes but as a result of interrogative pronoun decomposition into homonyms. From the chronological point of view, the mentioned above derivational means of negative and indefinite pronoun formation is the oldest one which is proved with the existence of such homonyms in dialects and substandard language to compare with the literary language reflecting the most archaic linguistic forms [35]. The secondary evidence is the fact that ion other languages both interrogative and indefinite pronouns also develop from interrogative ones [36]. Those three classes are united by their common seme 'ignorance/innocence'. 
The validity of the negative pronoun ancient origin dealing with interrogative ones is confirmed by etymological dictionaries data, e.g., "Of Common Slavonic

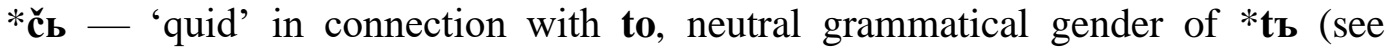

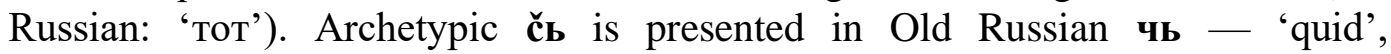
Ukrainian нич - 'ничего' (*ni-čь), Old Slavonic ничьже — 'ничто', оуничьжити — 'уничтожить', Serbo-Croatian чак, ча (*̌̌ь) — 'что', Old Slovenian nì̌, Old Czech nač — 'на что, к чему', proč — 'почему', Slovak nič — 'ничего', Polish zacz — ‘за что’ (...)» [37].

In Russian the interrogative pronoun $4 m o$ is formed as a combination of interrogative $4 b$ and demonstrative mo pronouns [38].

As for now, the homonymy of interrogative, relative, indefinite pronouns has been already described $[32 ; 35 ; 39$. P. $158-231 ; 40$. P. 157; 41. P. 18-26; 42; $43 ; 44]$. At a lesser degree, the homonymy of interrogative and attributive pronouns is still under the study [45]. The issue of interrogative and negative pronouns has been firstly put forward.

The S.I. Ozhegov and N.Yu. Shvedova dictionary deals with indeclinable pronouns $4 m o$, and the meaning of one of those is that: " 6 . Indeclinable. About what has no imoportance, does't play any role: Что слова? Звук пустой. Что ему наставления родителей? Неприятности что, справимся. Что толку спорить? Что пользы ждать" [46]. Here we can obviously see two words: in expressions of the type Что слова? — we qualify что as a negative pronounnoun; in expressions like Что толку спорить? We refer the indeclinable что to negative pronouns-adjective, and the latter two are the subject of our study.

V.I. Dahl distinguishes the interrogative pronoun umo with the meaning 'какой' and illustrates it with the following examples: “Что пользы врать? Что нужды! Пусть” [47]. It's rather чmo is meaning 'никакой' (lit.: 'not any') referring to necessity or use. We determine it as a negative pronoun-adjective.

D.N. Ushakov qualifies чmo of our studies as a relative pronoun thus uniting heterogeneous phenomena under one term: "5. relative pronoun. With the Genetive of nouns is used in the meaning 'how many/how much' (colloq.). Комар, что было сил, сонливца укусил (Krylov). The same refers to rhetoric questions and exclamations, and the meaning is 'many/much' (colloq.) Ymo денег истрачено (как много)! The same refers to rhetoric expressions: что то́лку, что по́льзы, что ну́жды (Old Russian, regional dialects) and others, often meaning 'no'? e.g., Что толку ('no reason') жить. Lermontov. Что ж прибыли, что ты высоко так заполз? (Krylov). — Ах, няня, няня, до того ли? Что нужды мне в твоем уме (Pushkin) [33]. Pronoun что of the first group of examples (Комар, что было сил, сонливца укусил) we qualify as a pronounnumeral In rhetoric expressions of the type Что толку жить or Что нужды мне в твоём уме we correlate что to the group of negative pronouns-adjectives.

In the dictionary of S.A. Kuznetsov, neither parts-of-speech attribution of the following pronoun ymo nor its lexico-grammatical class are defined, but the word itself has got the interpretation: "5. Nominative case only: чmo (colloq.) "Ничmо, ничего не значит. Что нам снег? Что ему слава? Что ему просьба 
родителей? Неприятности что, справимся. Что толку спорить? Что nользы грустить?" [48]. This что we consider both as a negative pronoun-noun as of examples: Что нам снег? and also as a negative pronoun-adjective as of example: Что пользы грустить.

The Concise academic dictionary also omits the parts-of-speech code of the word чmo, but fixes that it has got two meanings in different use, which are interpreted through the words 'ничто' и 'какой': “7. In (Russian - I.T.) rhetoric questions and exclamatory sentences it denotes: 'ничто, ничего, ничего не значит'. Что враги? пусть клевещут язвительней, Я пощады у них не прошу. (N. Nekrasov); Рыцарь на час. - Нет, тут дело не в лампах! Ламnы чmó!.. Тут штука вот какая: вентиляции настоящей не было. (V. Veresayev). || In combination with an abstract noun in Genitive case it is used to mean 'какой': “Что нужды мне в твоем уме? Желанья!.. что пользы напрасно и вечно желать? (M. Lermontov)" [49].

Чmo with a "concrete" noun (Что лампь) ) we treat as a negative pronounnoun. Ymo combined with "abstract" nouns in sentences of the like: Ymo нужды мне в твоём уме? (что in combination with the words проку, нужды, прибыли, пользы, толку, добра, выгоды) reveals the meaning 'никакой' (lit.: 'none', 'not any'). Чmo with a "concrete" nouns as they are coded in the dictionary, doesn't form a word combination, but makes a predicative word collocation to fulfill the predicative function. Later on we're going to demonstrate that to denote the subject by the negative pronoun-noun чmo "abstract" nouns could be used. Чmo combined with the words проку, нужды, прибыли, пользы, толку, добра, вblгодbl forms one-piece word collocation to fulfill the predicative function.

The dictionary by V.V. Morkovkin and al. [30. P. 380] states the existence in Russian of the substantive negative pronoun чmo meaning 'нет такого явления, предмета' (lit.: 'nothing of the kind of phenomenon or thing'), functioning in rhetoric questions like Что может быть вкуснее? This pronoun differs from the one we're studying in the article: in used to be substituted by two words 'ничего не' (lit.: 'nothing similar') instead of the one 'ничто' ('ничего') under the analysis. The meaning of the pronoun under the analysis is different: 'nonsignificant from somebody's point of view' ('as if it doesn't exist (for the authorizer)').

To sum up, the Russian dictionaries by V.I. Dahl, D.N. Ushakov, S.I. Ozhegov, S.A. Kyusnetsov, A.P. Yevgenyeva specify the examples of the negative pronoun-noun чmo, though the given facts are qualified in a different way.

According to Frequency dictionary, the word $4 m o$ occupies the seventh place as to its use, after the words в (во), и, не, на, я, быль [30. P. 807]. According to Zipf law, there's direct dependence between the frequency to use a word and the number of its meanings: in speech, the higher the frequency - the greater polycemy degree it obtains [51. P. 79]. On the other hand, M.A. Sorokina comments on the prerequisites of the word transitivity into another part of speech, or homonym referring to its polysemy and abstractness [19. P. 4]. The monography by B.P. Ardentov and dissertation by O.Yu. Stepanova study the pronoun ymo. B.P Ardentov gives examples with чmo meaning 'неважно, не имеет значения' 
(lit.: 'not important, of no importance') Чmo yмереть?; чmо meaning 'напрасно, зря' (lit.: 'in vain') Что так стоять?; meaning 'незачем' (lit.: 'useless') Что мне бояться?; meaning 'мало' (lit.: 'a little') Что хорошего?; Что толку? [27. P. 28-30] without denoting the basis to discriminate the use of "ymo in impersonal sentences" and without considering the meanings under discussion.

According to O.Yu. Stepanova, the umo homocomplex includes the interrogative pronoun чmo, чmo of the uncertainty semantics, чmo of the improper questions. Among the latter (ymo of the improper questions) there are rhetoric questions and the functioning of $4 m o$, is commented, "The interrogative umopronoun as a member of rhetoric question correlates with the class of negative pronouns: Что ('ничего') может быть выле мира в семье и работы? (B. Pasternak); Что ('ничто') страсти? - ведь рано иль поздно их сладкий недуг // Исчезнет при слове рассудка... (M. Lermontov)” [31. P. 6; 8].

"Russian Grammar" qualifies чmo as an interrogative word in the sentences of phraseological structure, e.g., Что мне страхи на старости лет?, Что толку?, Что пользы спорить?, Что мне до них? [52]. Что мне страхи на старости лет? и Что мне до них?, but belonging to various groups. From the point of view of the form, one can agree: the preposition adds its meaning in the second sentence. But что is the same. Что толку? appears to belongs to the same group together with Что нового?, but in the first sentence, что could be substituted by никакого (not any), while in the second one, ничего (nothing) appears which is why making up one and the same group is improper for the pronoun $4 m o$ is different in the two sentences.

S.M. Kolesnikova qualifies чmo as a gradual particle in the following examples: Что деньги! Дело наживное., Что твоё жалованье! Не надо его совсем., Нам награда что!, Я что., Да ведь что ж этот бал! Только, чай, слава, что бал., Ну что там агроном! Что он понимает по коровьим делам!, Да только что же выговор? Я и сам себя распекал не жалеючи. Служба что. Сам себя веди аккуратно, только и всего., "Анна Каренина» что! Там ничего нет определённого. Still, she writes that "in such use, umoconserves its connection with pronouns, because it reveals the element of the predicative meaning" [49]. As it seems, the gradual semantics is not a reason to associate with particles those words that fulfil predicative function. The negation possesses graduality [53. P. 232-292]..

The conclusion follows: negative pronoun чmo hasn't been properly studies by linguists.

\section{Negative pronoun-noun 4то \\ Negative pronoun-noun 4 TO functioning as a predicate of the two-member sentences}

Negative pronoun-noun umo fulfils the syntactic function in the two-member sentences. The subject at the negative pronoun-noun ymo more often is a noun, or pronoun-noun (e.g., эmo), or infinitive. Subject of the predicate expressed by the 
negative pronoun-noun umo could be a noun of any lexico-grammatical class, proper or nominal, animated and non-animated, concrete and corporeal, collective, concrete objective and abstract, e.g.: Гекуба, Помпея, Везувий, арфьл, бой, буря, скала, забег, беды, былое, века, вертеп, вечность, вихрь, воспоминания, вселенная, глумленье, горе, горы, дар, деньги, дом, дорога, заводы, зной, капризы, клавесины, клич, книги, месяи, мир, народ, нежность, песок, порыв, почёт, престиж, приговор, прочедчее, пятна, рынок, свобода, сила, сиянье, скорбь, скрипач, слеза, слёзы, слово, слова, сроки, суд, толки, траур, треск громов, толпьл, труд, тряпки, угол родной, универсамы, фразы, хула, штиль and many others. See:

Что ему природы горе, Если грез душа полна! (Vs.A. Rozhdestvensky). Что ему морок устроить, предстать коридором, чревовещательной щзелью, подставленной ловко, стать очевидным, опутать тебя договором, словно стоустой, услужливой татуировкой? (Zhdanov). Всё пошло на убыль: Стал Серёжка пить. И казённый рубль, Что ему пропить (Kropivnitsky).

With the что predicate there could be used a link было in various gender and number forms: Что ему были вражьи своры? Весь он был воплощуенная мecmb! (Slutsky).

Two-member sentence with the negative pronoun-noun ymo could be incomplete it could lack the subject. The omitted subject could be restored from the context, e.g.:

Сам мучитель, знаком уицраора Отраженный в шифре этих строк, Не облек бы столь всеобщим трауром Русский север, запад и восток. Что ему? Верховнейшая цельь Его жажды и могучих дел - Расширять державуцчитадель За черту, за грани, за предел (D.L. Andreyev). Что ему русский траур? Играет странный гармонист, Закинув голову высоко. И деньги падают, звеня, За пляску, полную азарта. Со взвизгиванием коня, С журчаньем рваного итандарта. Но гармонисту... / Что ему? Он видит саблю и уздечки... И снова зарево атак... Но лишь уходят с поля танки, Разучивает краковяк На взвизгивающей тальянке (Kornilov). Что ему деньги? Только песни будто бы светлее, только песни все обман, Ночью выйдет ясный месяи, - что ему... Серебро кругом развесит - ни к чему (Dryakhlov). Что ему месяц? Пусть в полях распустились цุветь Над шатрами бездонно-лазурныли, Что тебе, раз такими ж, как тыл, Полньл темные, душные тюрьмыз? (Kedrov). Что тебе весна?

The predicate presented in the form of the negative pronoun-noun ymo at the greatest large stays in a preposition to a subject, although another word order of those is possible: Так было в Лондоне, в Берлине и в Париже! Но это что emy? (Sluchevsky).

It's useful to distinguish active and passive combinability [12. P. 9], and for negative pronouns umo the active combinability is more typical: the question goes from them to the dependent word. 
In sentences with the negative pronoun-noun ymo the subject of evaluation is denoted by the Dative case noun form or personal pronoun of any person and number. G.A. Zolotova defines the meaning of the syntaxeme as "Dative of authorizer, with whose point of view phenomena and notions are being correlated" [55. P. 126]. It's a modes case meaning which different from dictum modus [the division of case meanings into modus and dictum see: 56], haven't yet got linguistic attribution and description, e.g.:

«Что нам книги без картинок?» - И старье забросят в печь (Vega). Что вам любовь или ненависть каких-то Горленко или Лизогубов? (Verbitskaya). Что им универсамы и заводы (Lipkin).

The emphasis of the subject could be omitted, if it's known from the previous sentence:

Вот чудак, ужели трудно Уяснить простой закон: Так ли, сяк ли беспробудный Ты уже вкушаешь сон. Что тебе привычки тела? Что там койка и постель?.. (Tvardovsky). Что мне сила моя, что моя бесполезная нежность, - Мне она не нужна, потому что тебе не нужна (Alexeyeva).

The negative pronoun чmо is replaced by the negative pronoun ничто (lit.: 'nothing'). The negative pronoun-noun ymo is used in the rhetoric question.

Rhetoric question is defined as an affirmation in the negative form or a negation in the affirmative form. "Specifics of rhetoric questions means that the sentences having no negative particle ' $\mathrm{He}$ ' in their structure, are perceived as negative, and vice versa, the sentences having a negative particle ' $\mathrm{He}$ ' in their structure, are understood as affirmative" [57. P. 267]. This very feature of rhetoric questions let clearly state that negative pronoun чmo in the sentences analyzed in the article, is replaces by the negative pronoun нuчmo (lit.: 'nothing').

The sentences with the interrogative pronoun-noun ymo render the negation in the affirmative.

\section{Negative pronoun-noun 4то functioning as the main member of the negative genitive sentences}

There are some sentences that denote the evaluative entity of negative pronoun-nouns containing the denotation by a noun in oblique case forms. They often replace что with ничего (lit.: 'nothing').

Negative genitive sentences with negative pronoun $4 m o$ functioning as the main sentence member the object evaluated could be rendered by a noun in Genitive case with prepositions $\partial o$ ('till, up to') or $c$ ('with') and a noun in Prepositional case with the preposition 6 ('in'). Sentences with the object of evaluation rendered by a noun with preposition $c$ ('with') (according to G.A. Zolotiova, the meaning of such syntaxeme is causative-2 [55. P. 99] and belongs to animated nouns only, but our catalogue registers only non-animated nouns): do evaluate as a whole only the object involved from outside as an object of evaluation formed with preposition $\partial o$ : according to "Russian Grammar", it's understood as "the reference negation" [52. P. 392-393]), while sentences with 
the object rendered by a n noun with the preposition 8 ('in'), do evaluate the object from inside aggregating its qualities and features (in the dictionary by G.A. Zolotova, the meaning of this syntaxeme is 'the subject bearing a feature' [55. P. 305]), see below:

Гром живет своим накатом - Что ему до наших бед? (Мандельштам). А я говорила - что мне с вашего парашюта? (Gerasimov). Не в самолюбии тут дело. да ито мне с моего самолюбия? (Correspondence in: icq agd-ardin и Герда (2008.02.19). Не дай Бог было при ней убить паука или мушку, или равнодушно наступить на какого-нибудь жучка. - Ну и что тебе с того? - сердито вопрошала она убийу. - Всех, ведь, не перебьёшь! (Zhelikhovskaya). И что ему, бродяге полумира, $\boldsymbol{B}$ твоем родном, единственном угле? (Tvardovsky).

So, despite the indeclinability, the negative pronoun-noun ymo reflects the meaning of two cases: Nominative and Genitive. In negative genitive sentences unnecessity, unimportance and insignificance of the object of evaluation is greater than in two-member sentences with the negative pronoun-noun ymodue to its degradation into the subordinate sentence member.

The negative pronoun ничто reveals three meanings: 1) ontological vacuum, the absence of an object; 2) something insignificant, unimportant, deserving no attention; 3) the negation of a person, the nonentity. The negative pronoun-noun umo reflects the meaning of 'something insignificant, non-essential, deserving no attention' which range up to '(as if) non-existence, absence (for an authorizer)'. In sentences with the preposition $c$ the meaning of ymo is 'the absence of usefulness, or uselessness'.

\section{Differences of Russian negative and interrogative pronoun-nouns что}

The negative pronoun-noun чmo belongs to the same formal class as the interrogative pronoun-noun $4 m o$, but their inflectional paradigm differs: while the interrogative pronoun is declined, varying in case forms, the negative one doesn't. The negative pronoun-noun umo has no relevance to the category of animacy/nonanimacy thus being different from the interrogative one, as well.

The interrogative pronoun чmo is divided into the radical and inflection -To, while the negative one has got just the stem but no The interrogative pronoun umo inflection neither zero one nor the materially explicated. The interrogative чmo forms a large family of words: indefinite and negative pronouns are formed there; but the negative umo has no derivatives.

Both negative and interrogative pronouns чmo have different synonyms: 'что такое?' of the interrogative, and 'ничто' ('ничего') of the negative; and antonyms: 'всё' of the negative, and no antonyms of the interrogative. Both чmo are similarly translated into foreign languages. The interrogative pronoun ymo is not limited in its combinability as it has an independent lexical meaning. The negative pronoun ymo the meaning is syntactically limited to the function of a 
predicate or the principle member in the negative genitive sentence and is structurally governed as it's used in the construction with the name of the evaluative subject (authorizer) in the Dative case form.

The meaning of the Dative case of the addressee or dependent object by the interrogative чmo is a dictum one; and at the negative pronoun umo the Dative of modus is used to signify the meaning of the authorizer (when it's omitted, it is still implicated: the pronoun всем or the concrete context noun replaces the subject of evaluation).

The interrogative чmo could represent any sentence member while the negative one is strictly a predicate or the principle member in the negative genitive sentence.

The negative чmo demands a specific emotional evaluative intonation and is used in colloquial constructions. The interrogative umo could be used on stylistically neutral sentences, in bookish style texts, an in colloquial speech.

The negative чmo is also used in sentences of phraseological structure, while the interrogative umo is spread in sentences of any structure, both one- and twomember ones, complete and incomplete ones, simple and complex ones.

A number of lexicologists are inclined to use to discriminate homonymy and polysemy the semantic criterion proper: they mean polysemy when there's a semantic connection of meaning; when there're none of the kind, they define homonymy. The interrogative and negative umo pronouns are not related either in metaphor or metonymy, or hypero-hyponimic and associative meanings.

The etymological correlation of interrogative and negative pronouns umo is evident. Any interrogative pronoun could be used in rhetoric questions rendering the meaning of the negative pronoun ymo (an example was given above). So, the question goes whether there's any typically polysemantic regularity? The answer is "no' as such negative pronouns refer to the Russian constructions with cumulative double negation, e.g., Что он скажет в оправдание? - Ничего не скажет. Russian pronoun ничто (ничего) replaces что.

So, the interrogative and negative pronouns чmo are homonyms.

\section{Negative pronoun-adjective 4 Tо \\ Negative pronoun-adjective что as a member of a word-combination functioning as the principle member in the negative genitive sentence}

The negative pronoun-adjective ymo is used $\mathrm{t}$ denote the meaning of the Genitive case of the following Russian nouns: пользы, проку, добра, выгоды, толку, прибыли, добра; it's replaced by the Russian negative pronoun никакого(ой). The negative pronoun-adjective что forms the integral wordcombination and fulfils the function of the principle member in the negative genitive sentence [58-62; comp.: 63-68]. See:

Пусть я уйду в иголку, но что мне в этом толку? (Zdanov). А что мне проку, когда ты не проворнее, чем свет, когда не поспеваешь к сроку? 
(Ptrov). Ничто не вечно под луной, да и что пользы человеку от трудов его, которыми трудится он под солнием? (Dezhnev). Он имеет сестру и брата, Hy, а что ему в том добра-то? (Simonov).

The indication of the evaluative subject could be omitted, and the subject is replaced by всем оr никому (lit.: 'to all or no one'), or the sentence is incomplete: the subject is reconstructed from the preceding context:

Что пользы в том, что явных казней нет? (Pen'kov). Только что проку от его красноречия, если после сказанного слова реальная жизнь идет совсем другим курсом? (Voschanov). Чем же славен? Что добра в твоих волнах? Что так шумен, своенравен Расплескался в берегах? (Shevyrev).

The object which is evaluated as of no use, usefulness, advantage, profit or benefit, is rendered by a noun in Genitive with the preposition om ('from') or a noun in Prepositional with the preposition $в$ ('in'). The object of evaluation with the preposition om ('from') denotes the evaluation of a reason (in the dictionary by G.A. Zolotova "in expressive modification of evaluative model, the component meaning a subject or causer of potential action, its pragmatic or emotional consequences are evaluated in the sentence" [55. P. 81]); the object of evaluation with the preposition 8 ('in') indicates the object evaluation from inside combining its qualities and features.

\section{Negative pronoun-adjective 4 то in the whole word-combination functioning ad a predicate of the two-member sentence}

The negative pronoun-adjective $4 m o$ in the whole word-combination with Russian nouns of пользы, проку, толку, добра, выгоды, прибыли is used as a predicate of the two-member sentence with the subject denoted by the infinitive:

И что проку археологу поспешать в Ezипет? (Golyandin). Что тебе пользы, Хирург беспощуадный, терзать мою душу? (Maikov). Но что толку выяснять отношения с официантами (Rubina).

In the $18^{\text {th }}$ century and the first three decades of the $19^{\text {th }}$ century, the negative pronoun-adjective чmo was still used in the word-combination with the Russian noun прибыли oin two-member and negative genitive sentences, but nowadays such use doesn't occur, see:

Вот, жена, - говорил мужской голос, - как добиваются в чины, а что мне прибыли, что я служу беспорочно, не подамся вперед ни на палец (Rasdischev). В самом деле, что тебе прибыли меня обманывать? (Zagoskin). Батюшка, не погуби ты меня, что тебе прибыли? (Fonvizin). Что вам прибыли губить меня? (Zagoskin).

There're just single examples with the Russian noun добра.

Why do we insist that the negative pronoun-adjective чmo is substituted by никакого? Our catalogue contains a lot of samples with expressions с никакого толку, никакого проку, никакой пользы, никакой выгоды, but only a few - 6! with с ничего толку: С самого Покрова учусь, учусь и... ничего толку... (Chekhov). Examples with с ничего проку, ничего ничего выгоды, ничего 
nользы, ничего добра are not found in the national Corpus of the Russian language. The negative pronoun-adjective чmo in the whole word-combinations что толку, проку, пользы, выгоды, добра, different from от никакого толку, проку, выгоды, пользы, ничего толку, are never used with the connector of the Future or Past Tense, or in Present Tense with нет. The negative pronoun никакого doesn't form the whole word-combinations with the words проку, толку, пользы, выгоды, different from the negative pronoun-adjective что.

The negative pronoun-adjective что means 'ни один из имеющихся или возможных' (lit.: 'not a single one at present or potential future'), while the negative pronoun никакой reveals only one of those meanings.

И что проку археологу поспешать в Египет? (Golyandin). Что тебе пользы, Хирург беспощуадный, терзать мою душу? (Maikov). Но что толку выяснять отношения с официиатами (Rubina).

In the $18^{\text {th }}$ century and the first three decades of the $19^{\text {th }}$ century, the negative pronoun-adjective umo was still used in the word-combination with the Russian noun прибыли oin two-member and negative genitive sentences, but nowadays such use doesn't occur, see:

There're just single examples with the Russian noun добра.

Why do we insist that the negative pronoun-adjective чmo is substituted by никакого? Our catalogue contains a lot of samples with expressions с никакого толку, никакого проку, никакой пользы, никакой выгоды, but only a few - 6! with с ничего толку: С самого Покрова учусь, учусь и... ничего толку... (Chekhov). Examples with с ничего проку, ничего ничего выгоды, ничего пользы, ничего добра are not found in the national Corpus of the Russian language. The negative pronoun-adjective чmo in the whole word-combinations что толку, проку, пользы, выгоды, добра, different from от никакого толку, проку, выгоды, пользы, ничего толку, are never used with the connector of the Future or Past Tense, or in Present Tense with нет. The negative pronoun никакого doesn't form the whole word-combinations with the words проку, толку, пользы, вьгодыь, different from the negative pronoun-adjective что.

The negative pronoun-adjective чmo means 'ни один из имеющихся или возможных' (lit.: 'not a single one at present or potential future'), while the negative pronoun никакой reveals only one of those meanings.

\section{Conclusion}

In summary, the Russian language possesses two negative pronouns чmo, the pronoun-adjective meaning 'никакого(ой)' (lit.: 'none', 'not any') and the pronoun-noun meaning 'ничто' /'ничего' (lit.: 'nothing'). As we consider interrogative and negative pronouns be the members of different classes as well as recon they are different words, negative and interrogative pronouns-nouns ymo should be assumed to be different words. As far as we discriminate two different pronouns-nouns and Russian pronouns-adjectives всё, это, mо, we have to admit that the negative pronoun чmo as a pronoun-noun, and the negative pronoun umoas 
a pronoun-adjective are also two different words. Despite the indeclinability, the negative pronoun-noun ymo reveals the meaning of two cases: Nominative and Genitive; the negative pronoun-adjective чmo always presents the meaning of the Genitive case, either of masculine or feminine gender. Both the negative pronounnoun чmo and the negative pronoun-adjective umo fulfil the function of the principle member of the negative genitive sentences. The specification of such genitive sentences concerns the negation being expressed in the affirmative, because negative pronouns $4 m o$ function in rhetoric questions in the negative meaning without negative affixes. Meanings of both negative pronouns umo are limited by the function of a predicate or principle sentence member of genitive sentences) and structurally dependent (as it is seen in the construction with the subject of evaluation - authorizer — in the Dative case form). The meaning of the negative pronoun adjective $4 m o$ is also phraseologically confined, as in this meaning, the pronoun чmo is used with one of the following Russian words: прокy, толку, пользы, выгодыl, прибыли, добра. Among the three mentioned above meanings of the negative pronoun ничто, the negative pronoun-noun means 'нечто неважное, несущественное, незначительное' (lit.: 'something insignificant'), or ('as if non-existing for the authorizer'), or 'uselessness', 'the lack of use'. Among the meanings of the negative pronoun никакой, the negative pronoun-adjective что reflect the one of 'ни один из имеющихся или возможных' (lit.: 'none of the existing or potential').

\section{Введение}

Целью нашей статьи является доказательство наличия в русском языке отрицательного местоимения-существительного что в значении «ничто» («ничего») и отрицательного местоимения-прилагательного что в значении «никакого(ой)». Отсюда вытекают задачи: описать лексическое значение, грамматические признаки и синтаксические функции вопросительных местоимений что, установить, являются они значениями многозначного вопросительного что или омонимами его и друг друга.

Актуальность темы определяется необходимостью установления полного состава (списка) местоимений в русском языке, а также важностью разработки критериев разграничения омонимии и полисемии в классе местоимений, значимостью исследования явлений функциональной омонимии, переходности и синкретизма.

Местоимений в русском языке гораздо больше, чем их перечислено в школьных и вузовских учебниках, трудах лингвистов. Принципиально важным для нас является утверждение М.И. Откупщиковой: «Основной способ производства местоимений - создание омонимичных значений (...) Одним из характерных способов пополнения классов местоимений является омонимия, имеющая глобальный характер в том смысле, что омонимичными оказываются не только отдельные местоимения, но и целые 
разряды, как, например, разряды вопросительных, относительных и кванторных К-местоимений» [1. С. 81].

Встает вопрос: вопросительное и отрицательное что - это разные слова, или разные значения многозначного слова? На сегодняшний день критерии разграничения омонимов и значений многозначного слова во многом совпадают, и вопрос о разграничении омонимии и полисемии остается открытым [2. С. 111-112; 3. С. 42; 4; 5] - общими являются следующие критерии: 1) различие категориального значения, для местоимений разряда по форме, или по соотношению с другими частями речи; 2) различие морфологических категорий, полноты формообразовательных парадигм; 3) различие морфемного состава; 4) наличие различных словообразовательных гнёзд; 5) разная сочетаемость с единицами других классов (морфологическая, лексическая, синтаксическая), разный объём лексической дистрибуции, разный круг синтаксических валентностей; различие синонимов и антонимов; 6) различный перевод на иностранные языки; 7) разная стилистическая характеристика; 8) сочетание с разной интонацией; 9) отличный структурно-семантический тип предложения, в котором используется слово. Только один критерий не повторяется: при полисемии значения слова связаны между собой непосредственно или опосредованно деривационными отношениями, т.е. отношениями типичной для данного языка семантической производности [3. С. 79]. Типичность, повторяемость, неуникальность связи между двумя значениями говорит о полисемии, и наоборот, единичность, исключительность, уникальность связи указывает на омонимию [6. С. 209]. Многозначность в принципе регулярна; омонимы имеют семантически не связанные значения [6. С. 193].

Продемонстрировать различия вопросительного местоимениясуществительного что и отрицательного местоимения-существительного что - разрешимая задача.

Отграничить от них отрицательное местоимение-прилагательное что на первый взгляд проще, поскольку это слова разных разрядов по форме, или по соотношению с другими частями речи. В лингвистических работах данный вопрос поднимается в связи с разработкой понятий «омокомплекс», «функциональные омонимы», «полифункциональные слова», синхронические процессы переходности в системе частей речи (см. краткую историю становления и развития теории синхронной переходности: [7]). С другой стороны, в толковых словарях омокомплексы (термин введён О.С. Ахмановой [2. С. 160]; широкое распространение получил благодаря работам В.В. Бабайцевой и её последователей [8-20]) подаются как многозначные слова. Считается, что одним из следствий непрерывных процессов переходности в грамматическом строе русского языка является возникновение функциональных омонимов - «этимологически родственных слов, совпадающих по звучанию, но относящихся к разным частям речи» [21. С. 194] и синкретичных образований, совмещающих в различной мере свойства оппозиционно противопоставленных частей речи. Совокупность функцио- 
нальных омонимов и синкретичных образований, совмещающих признаки разных частей речи, обозначают термином омокомплекс [21. С. 195]. Возникающие при этом промежуточные единицы называются гибридными словами (термин В.В. Виноградова), или контаминантами (термин Е.Н. Сидоренко [22; 23]). Синкретизм определяют как универсальное свойство языка, проявляющееся в способности языковой единицы выражать комплекс противопоставленных лексических и/или грамматических значений [7. С. 8]. Синкретизм - явление узуальное, естественное, универсальное, свойственное отдельным единицам и системе языка в целом [7. С. 28]. Но оказывается, что определить статус местоимения прилагательного что тоже не так просто. М.А. Стернина утверждает: «Приобретение отдельным значением слова новой частеречной семы не может автоматически вести к разрыву тождества слова и образованию омонимов. Основным признаком омонимии в плане содержания следует, на наш взгляд, считать отсутствие семантической производности значений (...) При наличии семантической связи между значениями мы имеем дело с полисемантичным словом, при отсутствии подобных связей - с омонимами» [24. С. 7]. Мы придерживаемся другой точки зрения, разделяемой большинством лингвистов, считающих функциональные омонимы разными словами на основании их принадлежности к разным частям речи $[9 ; 10$. С. 7; 12. С. 7; 25. С. 25; 26. С. 6].

В словарях наречия что, местоимения что (вопросительное, определительное, относительное, неопределённое, с одной стороны, местоимениесуществительное, местоимение-числительное, местоимение-прилагательное, с другой) подаются как значения одного слова. Получается, что слово в разных значениях может принадлежать к разным частям речи ( Что принёс? - местоимение. Что так поздно пришёл? - наречие причины. Что вы приезжали? наречие цели $[27 ; 28$. С. $27-29 ; 29$. С. $817 ; 30$. С. 380; 31. С. 78-81]) или к разным лексико-грамматическим разрядам (Что лежит на окне? - вопросительное местоимение-существительное. Узнай, что он ответил. - относительное местоимение-существительное. Спой песню, что певала мама. - относительное местоимение-прилагательное с признаками местоимениясуществительного [32. С. 60]. Узнаешь что, сообщай незамедлительно. - неопределённое местоимение-существительное. Что просишь за эти бусы? вопросительное местоимение-числительное. Что есть духу, давай стрекача. относительное местоимение-числительное. У Д.Н. Ушакова приводится разделительное местоимение что в значении «одно - другое»: «Что забыл, а чего и не знал никогда. Очень уж он неаккуратен: что перепутает, что потеряет, о чем забудет» [33]. Логичнее было бы квалифицировать его как определительное местоимение-существительное [Ср.: Т.Ф. Ефремова [34] как определительное квалифицирует что в значении «много»: Что здесь народу! Что в этом году воды!]).

Вопросительные местоимения являются производящей базой для относительных, отрицательных, неопределённых местоимений. Отрицательные и 
неопределённые местоимения образуются от вопросительных не только с помощью приставок или постфиксов, но и путём распада вопросительного местоимения на омонимы. С хронологической точки зрения последний способ образования отрицательных и неопределённых местоимений является самым древним, что доказывается бытованием омонимов в диалектах и просторечии, по сравнению с литературным языком отражающих наиболее архаичные состояния языка [35]. Косвенным доказательством является тот факт, что и в других языках неопределённые и отрицательные местоимения тоже развиваются из вопросительных [36]. Три данных разряда объединяет общая сема «незнание».

В истинности утверждения о древности происхождения отрицательных местоимений от вопросительных убеждаемся, обратившись к этимологическому словарю: «Из праславянского *с̌ь — “quid” в соединении с to, среднего рода от *tъ (см.: тот). Первоначальное с̌ь представлено в древнерусском чь — "quid", украинском нич — “ничего" (*ni-с̌ь), старославянском ничьже - “ничто”, оуничьжити - “уничтожить”, сербохорватском чак, ча (*с̌ь) — “что”, древнесловенском niс̌žе — “ничто”, словенском nі̀с, древнечешском піс̌, чешском пас̌ — “на что, к чему”, proč — “почему”, словацком nič — “ничего", польском zacz — “за что” (...)» [37].

В русском языке вопросительное местоимение что образовано сложением вопросительного чь и указательного местоимения то [38].

Омонимия вопросительных, относительных, неопределённых местоимений на сегодняшний день описана $[32 ; 35 ; 39$. С. $158-231 ; 40$. С. 157 ; 41. С. $18-26 ; 42 ; 43 ; 44]$. В меньшей мере освещена омонимия вопросительных и определительных местоимений [45]. Об омонимии вопросительных и отрицательных местоимений вопрос поднимается впервые.

Существование омонимии вопросительных и отрицательных местоимений было обнаружено лишь некоторыми лексикографами и получило отражение в нескольких толковых словарях, хотя квалифицированы данные языковые факты были иначе и по-разному у разных авторов.

В словаре С.И. Ожегова, Н.Ю. Шведовой описаны четыре несклоняемых местоимения что; об одном из них сказано: «6. несклоняемое. О том, что не имеет значения, не играет никакой роли. Что слова? Звук пустой. Что ему наставления родителей? Неприятности что, справимся. Что толку спорить? Что пользы ждать» [46]. Мы видим здесь два слова: в выражениях типа Что слова? квалифицируем что как отрицательное местоимениесуществительное; в выражениях Что толку спорить? относим несклоняемое что к отрицательным местоимениям-прилагательным, именно два последних местоимения являются предметом нашего изучения и описания.

В.И. Даль выделял вопросительное местоимение что в значении «какой» и иллюстрировал его среди прочего примерами: «Что пользы врать? Что нужды! Пусть» [47]. Скорее, значение такого что «никакой» (пользы, нужды). Мы относим его к отрицательным местоимениям-прилагательным. 
Д.Н. Ушаков отнёс интересующее нас что к относительным, объединив одним термином разнородные явления: «5. относительное. При род. П. сущ. употр. в знач. сколько (разг.). Комар, что было сил, сонливца укусил. Крылов. (...) || То же в риторическом вопросе, в восклицании употр. в знач. много (разг.). Что денег истрачено (как много)! (...) || То же в риторических выражениях: что то́лку, что по́льзы, что ну́жды (устар., обл.) и др. употр. в знач. нет. Что толку (нет толку) жить. Лермонтов. Что ж прибыли, что ты высоко так заполз? Крылов. — Ах, няня, няня, до того ли? Что нужды мне в твоем уме. Пушкин» [33]. Что в первой группе примеров (Комар, что было сил, сонливца укусил) мы квалифицируем как местоимение-числительное. Что в риторических выражениях типа Что толку жить или Что нужды мне в твоём уме относим к отрицательным местоимениямприлагательным.

В словаре С.А. Кузнецова ни частеречная принадлежность следующего что, ни его лексико-грамматический разряд не указаны, но слово получает толкование: «5. только именительный падеж: что. Разг. (в риторическом вопросе и восклицании). Ничто, ничего не значит. Что нам снег? Что ему слава? Что ему просьба родителей? Неприятности что, справимся. Что толку спорить? Что пользы грустить?» [48]. Такое что мы считаем отрицательным местоимением-существительным в примерах типа Что нам снег? и отрицательным местоимением-прилагательным в примерах типа Что пользы грустить.

В малом академическом словаре тоже не указана частеречная принадлежность слова что, но зафиксировано, что у него два значения в разных употреблениях, которые толкуются словами «ничто» и «какой»: «7. В риторических вопросах и восклицательных предложениях обозначает: ничто, ничего, ничего не значит. Что враги? пусть клевещут язвительней, Я пощады у них не прошу. Н. Некрасов, Рыцарь на час. - Нет, тут дело не в лампах! Лампь что́!. Тут штука вот какая: вентиляции настоящей не было. Вересаев, На мертвой дороге. || В сочетании с отвлеченным существительным в род. П. употребляется в значении: какой. Что нужды мне в твоем уме? (...) Желанья!.. что пользы напрасно и вечно желать? Лермонтов, И скучно, и грустно» [49].

Что с «конкретными» существительными (Что лампь) мы относим к отрицательным местоимениям-существительным. Что с «отвлечёнными» существительными в предложениях типа Что нужды мне в твоём уме? (что в сочетании со словами проку, нужды, прибыли, пользы, толку, добра, вblгодbl) имеет значение «никакой». Что с «конкретными» существительными, как они квалифицированы в словаре, не образует словосочетания, а составляет предикативное сочетание слов, в котором что выполняет функцию сказуемого. Ниже мы покажем, что подлежащим при отрицательном местоимении-существительном что может быть и абстрактное существительное. Что в сочетании со словами проку, нужды, прибыли, пользы, тол- 
ку, добра, выгоды образует цельное словосочетание, выполняющее функцию сказуемого.

В словаре В.В. Морковина и др. [30. С. 380] отмечается наличие в русском языке субстантивного отрицательного местоимения что в значении «нет такого явления, предмета», функционирующего в риторических вопросах типа Что может быть вкуснее? Это местоимение отличается от того, которому посвящена наша статья: на его место подставляются два слова «ничего не», на место анализируемого нами одно: «ничто» («ничего»). Значение «нашего» местоимения другое: «несущественно с чьей-либо точки зрения» («(как бы) не существует (для авторизатора)»).

Итак, в толковых словарях русского языка В.И. Даля, Д.Н. Ушакова, С.И. Ожегова, С.А. Кузнецова, А.П. Евгеньевой приведены примеры отрицательного местоимения-существительного что и отрицательного местоименияприлагательного что, хотя квалифицированы данные языковые факты иначе.

По данным «Частотного словаря», слово что занимает седьмое место по степени использования его в речи после слов в (во), и, не, на, я, быть [30. С. 807]. Согласно закону Дж. Ципфа, существует прямая зависимость между частотностью употребления слова и количеством его значений: чем выше частотность употребления слова в речи, тем большей степенью полисемии оно обладает [51. С. 79]. С другой стороны, М.А. Сорокина в качестве предпосылок переходности слова в другую часть речь, в омоним указала его посемантизм и абстрактность [33. С. 4].

Местоимению что посвящены монография Б.П. Ардентова и диссертация О.Ю. Степановой. Б.П. Ардентов приводит примеры с что в значении «неважно, не имеет значения» Что умереть?; что в значении «напрасно, зря» Что так стоять?; в значении «незачем» Что мне бояться?; в значении «мало» Что хорошего?; Что толку? [27. С. 28-30], не указывая оснований деления употреблений «"что” в безличных предложениях» на перечисленные группы.

Омокомплекс местоимения что, по О.Ю. Степановой, включает вопросительное местоимение что, что с семантикой неопределённости, что в несобственно вопросительных предложениях. Среди последних (что в несобственно вопросительных предложениях) в числе прочего выделены риторические вопросы, о функционировании в которых местоимения что говорится: «Вопросительное местоимение что в составе риторического вопроса коррелирует с разрядом отрицательных местоимений: Что (ничего) может быть выше мира в семье и работы? (Б. Пастернак) Что (ничто) страсти? - ведь рано иль поздно их сладкий недуг // Исчезнет при слове рассудка... (М. Лермонтов)» [31. С. 6; 8]. В примерах два разных местоимения что, нас интересует второе, заменяемое словом ничто; на место первого подставляются два слова «ничто не».

«Русская грамматика» квалифицирует что как вопросительное слово в предложениях фразеологизированной структуры типа Что мне страхи на 
старости лет?, Что толку?, Что пользы спорить?, Что мне до них? [52]. Что мне страхи на старости лет? и Что мне до них? оказываются в разных группах. С точки зрения формы это можно принять: предлог вносит своё значение во второе предложение. Но что в них одинаковое. Что толку? оказывается в одной группе с Что нового?, но здесь на место что в первом случае подставляется никакого, а во втором ничего, поэтому объединение предложений в одну группу представляется неправомерным: в них разное что.

С.М. Колесникова что в предложениях типа Что деньги! Дело наживное., Что твоё жалованье! Не надо его совсем., Нам награда что!, Я что., Да ведь что ж этот бал! Только, чай, слава, что бал., Ну что там агроном! Что он понимает по коровьим делам!, Да только что же выговор? Я и сам себя распекал не жалеючи.. Служба что. Сам себя веди аккуратно, только и всего., "Анна Каренина» что! Там ничего нет определённого. — квалифицирует как градуальную частицу, хотя пишет, что «что в подобном употреблении сохраняет связи с местоимением, именно в что обнаруживается элемент предикативного значения» [49]. Представляется, что градуальная семантика не повод отнесения к частицам слова, выполняющего функцию сказуемого. Отрицание обладает градуальностью [53. С. 232-292].

Итак, и в работах лингвистов отрицательное местоимение что не получило описания.

\section{Отрицательное местоимение-существительное что Отрицательное местоимение-существительное что в функции сказуемого в двусоставных предложениях}

Отрицательное местоимение-существительное что выполняет синтаксическую функцию сказуемого в двусоставном предложении. Подлежащее при отрицательном местоимении-существительном что чаще выражено существительным, или местоимением-существительным (например, это), или инфинитивом. Подлежащим при сказуемом, выраженным отрицательным местоимением-существительным что, может быть имя существительное любого лексико-грамматического разряда, собственное и нарицательное, одушевлённое и неодушевлённое, конкретное, в том числе вещественное, собирательное, конкретное предметное, и абстрактное, например: Гекуба, Помпея, Везувий, арфыл, бой, буря, скала, забег, беды, былое, века, вертеп, вечность, вихрь, воспоминания, вселенная, глумленье, горе, горы, дар, деньги, дом, дорога, заводыл, зной, капризы, клавесины, клич, книги, месяч, мир, народ, нежность, песок, порыв, почёт, престиж, приговор, прошедшее, пятна, рынок, свобода, сила, сиянье, скорбь, скрипач, слеза, слёзы, слово, слова, сроки, суд, толки, траур, треск громов, толпьl, труд, тряпки, угол родной, универсамы, фразы, хула, штиль и мн. др.

Что ему природы горе, Если грез душа полна! (Вс.А. Рождественский). Что ему морок устроить, предстать коридором, чревовещательной щее- 
лью, подставленной ловко, стать очевидньм, опутать тебя договором, словно стоустой, услужливой татуировкой? (Жданов). Всё пошло на убыль: Стал Серёжка пить. И казённый рубль, Что ему пропить (Кропивницкий).

При сказуемом что может быть связка было в разных родовых и числовых формах. Что ему были вражьи своры? Весь он был воплощценная месть! (Слуцкий).

Двусоставное предложение с отрицательным местоимениемсуществительным что может быть неполным, в нём может отсутствовать подлежащее. Пропущенное подлежащее восстанавливается из предшествующего контекста.

Сам мучитель, знаком уицраора Отраженный в иифре этих строк, Не облек бы столь всеобщим трауром Русский север, запад и восток. Что ему? Верховнейшая иель Его жажды и могучих дел - Расширять державуцчитадель За черту, за грани, за предел (Д.Л. Андреев). Что ему русский траур? Играет странный гармонист, Закинув голову высоко. И деньги падают, звеня, За пляску, полную азарта. Со взвизгиванием коня, С журчаньем рваного штандарта. Но гармонисту... / Что ему? Он видит саблю и уздечки... И снова зарево атак... Но лишь уходят с поля танки, Разучивает краковяк На взвизгивающей тальянке (Корнилов). Что ему деньги? Только песни будто бы светлее, только песни все обман, Ночью выйдет ясный месяи, - что ему... Серебро кругом развесит - ни к чему (Дряхлов). Что ему месяц? Пусть в полях распустились цветы Над матрами бездонно-лазурнылми, Что тебе, раз такими ж, как тыл, Полны темные, душные тюрымы? (Кедрин). Что тебе весна?

Сказуемое, выраженное отрицательным местоимением-существительным что, в подавляющем большинстве случаев предшествует подлежащему, хотя возможен и иной порядок главных членов предложения. Так было в Лондоне, в Берлине и в Париже! Но это что ему? (Случевский).

Различают активные и пассивную сочетаемость [39. С. 9], для отрицательных местоимений что характерна активная сочетаемость: вопрос задаётся от них к зависимому слову.

В предложениях с отрицательным местоимением-существительным что субъект оценки обозначен формой дательного падежа существительного или личного местоимения любого лица и числа. Г.А. Золотова определяет значение данной синтаксемы как «дательный падеж авторизатора, с точки зрения которого соотносятся, оцениваются явления и понятия» [55. С. 126]. Это модусное значение падежа, которые, в отличие от диктумных [деление значений падежей на модусные и диктумные см.: 56], не получили пока лингвистической инвентаризации и описания.

«Что нам книги без картинок?»- И старье забросят в печь (Вега). Что вам любовь или ненависть каких-то Горленко или Лизогубов? (Вербицкая). Что им универсамы и заводы (Липкин). 
Указание на субъект оценки может быть опущено, если он известен из предшествующего предложения.

Вот чудак, ужели трудно Уяснить простой закон: Так ли, сяк ли беспробудный Ты уже вкушаешь сон. Что тебе привычки тела? Что там койка и постель?.. (Твардовский). Что мне сила моя, что моя бесполезная нежность, - Мне она не нужна, потому что тебе не нужна (Алексеева).

На место отрицательного местоимения что подставляется отрицательное местоимение ничто. Употребляется отрицательное местоимениесуществительное что в риторическом вопросе.

Риторический вопрос определяют как утверждение в отрицательной форме или отрицание в утвердительной форме. «Особенностью риторического вопроса является то, что предложения, не имеющие в своём составе отрицательной частицы “не”, воспринимаются как отрицательные, и, наоборот, предложения, имеющие в своём составе частицу “не”, осознаются как утвердительные» [57. С. 267]. Именно данное свойство риторического вопроса позволяет однозначно утверждать, что на место отрицательного что в рассматриваемых в статье предложениях подставляется отрицательное местоимение ничто.

В предложениях с вопросительным местоимением-существительным что отрицание передаётся в утвердительной форме.

\section{Отрицательное местоимение-существительное что в функции главного члена в отрицательных генитивных предложениях}

Существуют предложения, в которых то, что оценивается отрицательным местоимением-существительным, может быть обозначено существительным в косвенном падеже с предлогами. В них на место что подставляется ничего.

В отрицательных генитивных предложениях с отрицательным местоимением что в функции главного члена предложения предмет оценки может быть выражен существительным в родительном падеже с предлогом до или с предлогом $c$, существительным в предложном падеже с предлогом 8. В предложениях с объектом оценки, выраженным существительным с предлогом $c$, оценивается причина (у Г.А. Золотовой значение подобной синтаксемы каузатив-2 [55. С. 99] указано исключительно с одушевлёнными существительными, в нашей картотеке только неодушевлённые); с объектом оценки, выраженным существительным с предлогом до, оценивается объект в целом, взятый извне (в «Русской грамматике» это обозначено как «отрицание касательства» [52. С. 392-393]); в предложениях с объектом, выраженным существительным с предлогом в, оценивается объект изнутри в совокупности его качеств и признаков (в словаре Г.А. Золотовой значение данной синтаксемы: «субъект - носитель признака» [55. С. 305]).

Гром живет своим накатом - Что ему до наших бед? (Мандельштам). А я говорила — что мне с вашего парашюта? (Герасимов). Не в самолюбии 
тут дело, да что мне с моего самолюбия? (Переписка в icq agd-ardin и Герда (2008.02.19). Не дай Бог было при ней убить паука или мушку, или равнодушно наступить на какого-нибудь жучка. - Ну и что тебе с того? - сердито вопрошала она убийу. - Всех ведь не перебьёшь! (Желиховская). И что ему, бродяге полумира, В твоем родном, единственном угле? (Твардовский).

Таким образом, несмотря на несклоняемость, отрицательное местоимение-существительное что имеет значения двух падежей: именительного и родительного. В отрицательных генитивных предложениях неважность, незначительность, ненужность объекта оценки для субъекта оценки выражена в большей степени, чем в двусоставных предложениях с отрицательным местоимением-существительным что благодаря его низведению в статус второстепенного члена предложения.

У отрицательного местоимения ничто выделяют три значения: 1) онтологический вакуум, небытие, отсутствие предмета; 2) нечто незначительное, несущественное, не заслуживающее внимания; 3) отрицание значимости какого-либо лица, ничтожество. Отрицательное местоимение-существительное что имеет значение «нечто незначительное, несущественное, не заслуживающее внимания», которое колеблется до значения «(как бы) несуществование, отсутствие (для авторизатора)». В предложениях с предлогом $c$ значение что «отсутствие (пользы, проку)».

\section{Различия отрицательного и вопросительного местоимений-существительных что}

Отрицательное местоимение-существительное что принадлежит к тому же формальному разряду, что и вопросительное местоимение что, но словоизменительные парадигмы у местоимений различаются: вопросительное местоимение изменяется по падежам, отрицательное не склоняется. Отрицательное местоимение что не имеет отношения к категории одушевлённости/неодушевлённости, в отличие от вопросительного.

Вопросительное местоимение что членится на корень и окончание -то, отрицательное состоит только из основы и не содержит окончания, ни нулевого, ни материально выраженного. Вопросительное что имеет большое словообразовательное гнездо: от него образованы неопределённые и отрицательные местоимения; у отрицательного что нет производных.

У отрицательного и вопросительного что разные синонимы: у вопросительного «что такое?», у отрицательного «ничто» («ничего»), и антонимы: у отрицательного - всё, у вопросительного нет антонимов. На иностранные языки и то, и другое что переводятся одинаково. Вопросительное что не ограничено в своей сочетаемости, у него свободное лексическое значение. У отрицательного местоимения что значение синтаксически ограниченное функцией сказуемого или главного члена в отрицательном генитивном предложении и конструктивно обусловленное (употребляется в конструкции с именем субъекта оценки (авторизатора) в форме дательного падежа). 
Значение дательного падежа при вопросительном что адресата или косвенного объекта, это диктальное значение; при отрицательном что употребляется дательный модусный падеж со значением авторизатора (там, где он опускается, он всё равно подразумевается: на место пропущенного субъекта оценки подставляется всем или конкретное имя из контекста).

Вопросительное что может быть любым членом предложения, отрицательное только сказуемым или главным членом в отрицательных генитивных предложениях.

Отрицательное что сочетается с особой эмоциональной и оценочной интонацией, употребляется в разговорных конструкциях. Вопросительное что может употребляться и в стилистически нейтральных предложениях, и в текстах книжных стилей, и в разговорном стиле.

Отрицательное что употребляется в предложениях фразеологизированной структуры, вопросительное что в предложениях любого типа, односоставном и двусоставном, полном и неполном, простом и сложном.

Часть лексикологов склоняется к использованию собственно семантического критерия разграничения омонимов и полисемантов: при наличии семантических связей между значениями говорят о полисемии, при отсутствии таковых - об омонимии. Вопросительное и отрицательное что не связаны ни метафорой, ни метонимией, ни гиперо-гипонимическими, ни ассоциативными отношениями.

Этимологическая связь вопросительного и отрицательного что налицо. Любое вопросительное местоимение может быть употреблено в риторическом вопросе со значением отрицательного, один из примеров мы приводили выше. Нет ли здесь регулярности, характерной для многозначности? Нет, такие отрицательные местоимения передаются конструкциями с кумулятивным, двойным отрицанием: Что он скажет в оправдание? - Ничего не скажет. На место описываемого нами что подставляется одно отрицание «ничто» («ничего»).

Вопросительное и отрицательное местоимения-существительные что омонимы.

\section{Отрицательное местоимение-прилагательное что Отрицательное местоимение-прилагательное что в составе цельного словосочетания в функции главного члена отрицательного генитивного предложения}

Отрицательное местоимение-прилагательное что употребляется в значении родительного падежа с существительными noльзы, npoкy, добра, вblгодbl, толку, прибыли, добра; на его место подставляется отрицательное местоимение никакого(ой). Отрицательное местоимение-прилагательное что образует цельное словосочетание с перечисленными словами и в составе данного цельного словосочетания выполняет функцию главного члена отрицательного генитивного предложения [58-62; ср.: 62-68]. 
Пусть я уйду в иголку, но что мне в этом толку? (Жданов). А что мне проку, когда ты не проворнее, чем свет, когда не поспеваешь к сроку? (Петров). Ничто не вечно под луной, да и что пользы человеку от трудов его, которыми трудится он под солнцем? (Дежнев). Он имеет сестру и брата, Ну, а что ему в том добра-то? (Симонов).

Указание на субъект оценки может отсутствовать, при этом предложение содержит обобщение: на место пропущенного субъекта оценки подставляется всем или никому, или предложение является неполным: субъект оценки восстанавливается из предшествующего контекста.

Что пользы в том, что явных казней нет? (Пеньков). Только что проку от его красноречия, если после сказанного слова реальная жизнь идет совсем другим курсом? (Вощанов). Чем же славен? Что добра в твоих волнах? Что так шумен, своенравен Расплескался в берегах? (Шевырев).

То, что оценивается как не имеющее пользы, проку, толку, выгоды, прибыли, добра, выражается существительным в родительном падеже с предлогом om или существительным в предложном падеже с предлогом. Объект оценки с предлогом от указывает, что оценивается причина (в словаре Г.А. Золотовой «в экспрессивной модификации оценочной модели компонент со значением субъекта или каузатора потенциального действия, прагматические или эмоциональные последствия которого оцениваются в предложении» [55. С. 81]); объект оценки с предлогом в указывает на оценку объекта изнутри в совокупности его качеств и признаков.

\section{Отрицательное местоимение-прилагательное что в составе цельного словосочетания в функции сказуемого в двусоставном предложении}

Отрицательное местоимение-прилагательное что в составе цельного словосочетания с существительным пользы, проку, толку, добра, выгоды, прибыли употребляется в качестве сказуемого в двусоставном предложении с подлежащим, выраженным инфинитивом.

В XVIII и первой трети XIX века отрицательное местоимениеприлагательное что употреблялось ещё в составе цельного словосочетания с существительным прибыли и в двусоставных, и в отрицательных генитивных предложениях, такое употребление не встречается уже в наши дни.

Вот, жена, - говорил мужской голос, - как добиваются в чины, а что мне прибыли, что я служу беспорочно, не подамся вперед ни на палец (Радищев). В самом деле, что тебе прибыли меня обманывать? (Загоскин). Батюшка, не погуби ты меня, что тебе прибыли? (Фонвизин). Что вам прибыли губить меня? (Загоскин).

Примеры с что добра тоже единичные.

Почему мы утверждаем, что на место отрицательного местоименияприлагательного что подставляется «никакого»? В нашей картотеке множество примеров с никакого толку, никакого проку, никакой пользы, никакой 
вblгодbl, но всего несколько (шесть) с ничего толку (С самого Покрова учусь, учусь и... ничего толку... [Чехов]). Примеры с ничего проку, ничего выгоды, ничего nользы, ничего добра отсутствуют в Национальном корпусе русского языка. Отрицательное местоимение-прилагательное что в составе цельных словосочетаний что толку, проку, пользы, выгодbl, добра, в отличие от никакого толку, проку, выгоды, пользы, ничего толку, никогда не употребляется со связкой будущего или прошедшего времени, а в настоящем времени с нет. Отрицательное местоимение никакого не образует цельного словосочетания со словами проку, толку, noльзbl, вblгодыl, в отличие от отрицательного местоимения прилагательного что.

Отрицательное местоимение-прилагательное что имеет значение «ни один из имеющихся или возможных», у отрицательного местоимения никакой это одно из значений.

\section{Заключение}

Итак, в русском языке существуют два отрицательных местоимения что, местоимение-прилагательное в значении «никакого(ой)» и местоимение-существительное в значении «ничто» («ничего»). Поскольку мы относим вопросительные и относительные местоимения к разным разрядам и считаем их разными словами, отрицательное и вопросительное местоимения-существительные что следует признать разными словами. Поскольку мы выделяем как два разных слова местоимения-существительные и местоимения-прилагательные всё, это, то, нужно признать, что отрицательное что - местоимение-существительное - и отрицательное что - местоимение-прилагательное - это тоже два разных слова. Несмотря на несклоняемость, отрицательное местоимение-существительное что имеет значения двух падежей: именительного и родительного; отрицательное местоимениеприлагательное что всегда выражает значение родительного падежа, мужского или женского рода. Отрицательные местоимение-существительное что и местоимение-прилагательное что выполняют функцию сказуемого в двусоставных предложениях или функцию главного члена предложения в отрицательных генитивных предложениях. Особенность данных генитивных предложений в том, что в них отрицание выражается в утвердительной форме, поскольку отрицательные местоимения что функционируют в риторических вопросах в отрицательном значении без аффикса отрицательности. Значения обоих отрицательных местоимений что синтаксически ограниченные (функцией сказуемого или главного члена отрицательных генитивных предложений) и конструктивно обусловленные (проявляются в конструкции с субъектом оценки - авторизатором - в форме дательного падежа). Значение отрицательного местоимения-прилагательного что ещё и фразеологически связанное, поскольку в данном значении что всегда употребляется с одним из следующих слов: проку, толку, nользы, вblгоды, nрuбыли, добра. Из трёх значений отрицательного местоимения ничто отрица- 
тельное местоимение-существительное что имеет значение «нечто неважное, несущественное, незначительное» (или «(как бы) несуществующее (для авторизатора)») или «отсутствие (пользы)». Из значений отрицательного местоимения никакой отрицательное местоимение-прилагательное что имеет значение «ни один из имеющихся или возможных».

\section{Библиографический список}

1. Откупщикова М.И. Местоимения современного русского языка в структурносемантическом аспекте. Л.: ЛГУ, 1984.

2. Ахманова О.С. Очерки по общей и русской лексикологии. М.: Учпедгиз, 1957.

3. Малаховский Л.В. Теория лексической и грамматической омонимии. М.: ЛИБРОКОМ, 2009.

4. Ким О.М. Транспозиция на уровне частей речи и явление омонимии в современном русском языке. Ташкент: Фан, 1978.

5. Качурин Д.В. Проблема разграничения омонимии и полисемии применительно к практике составления толковых словарей: автореф. дис. ... канд. филол. наук. М., 2014.

6. Новиков Л.А. Семантика русского языка. М.: Высш. шк., 1982.

7. Высоикая И.В. Синкретизм в системе частей речи современного русского языка: автореф. дис. ... д-ра филол. наук. М., 2006.

8. Бабайцева B.B. Местоимение ЭТО и его функциональные омонимы. М.: Флинта: Наука, 2016.

9. Богданова М.А. Форма, семантика и функции лексемы хорошо: автореф. дис. ... канд. филол. наук. М., 2014.

10. Емиева О.В. Слова более и менее в современном русском языке: автореф. дис. ... канд. филол. наук. М., 2010.

11. Жукова T.A. Полифункциональная лексическая единица «к слову» и ее контекстнофункциональные синонимы: автореф. дис. ... канд. филол. наук. Владивосток, 2003.

12. Ильина А.Б. «Гибридные» слова с градуальной семантикой в современном русском языке (наречия-частицы): Автореф. дис. ... канд. филол. наук. М., 2005.

13. Кириченко И.В. Семантические и функциональные особенности слова ПРОСТО в современном русском языке: автореф. дис. ... канд. филол. наук. Ставрополь, 2002.

14. Люлина E.A. Слово как в русском языке (семантика, морфологическая и синтаксическая характеристика, функционирование в стилевых разновидностях языка): автореф. дис. ... канд. филол. наук. Нижний Новгород, 2006.

15. Милованова М.С. Функциональные омонимы звуковых комплексов против / напротив и их грамматический статус: автореф. дис. ... канд. филол. наук. М., 2004.

16. Моргунова А.Н. Бытование омокомплекса оно в русском дискурсе: автореф. дис. ... канд. филол. наук. Самара, 2016.

17. Никитина О.В. Семантико-функциональные особенности слова «прямо» в современном русском языке: автореф. дис. ... канд. филол. наук. Майкоп, 2008.

18. Семенова О.В. Морфологический статус и синтаксические функции слова вроде: автореф. дис. ... канд. филол. наук: М., 2000.

19. Сорокина M.A. Функцианирование омокомплекса правда в современном русском языке: автореф. дис. ...канд. филол. наук. М., 2002.

20. Шамшин Ю.Н. Функционирование омокомплексов много и мало в современном русском языке: Автореф. дис. ... канд. филол. М., 2007.

21. Бабайцева В.В. Явления переходности в грамматике русского языка. М.: Дрофа, 2000.

22. Сидоренко E.Н. Очерки по теории местоимений современного русского языка. Киев, Одесса: Лыбидь, 1990. 
23. Сидоренко E.Н. Морфология современного русского языка. Части речи и контаминаты: учеб. пособие. М.: Флинта; Наука, 2017.

24. Стернина М.A. Лексико-грамматическая полисемия в системе языка (опыт разработки интегральной теории полисемии): автореф. дис. ... д-ра филол. наук. Воронеж, 2000.

25. Арсеньева М.Г., Строева Т.В., Хазанович А.П. Многозначность и омонимия. Л.: ЛГУ, 1966.

26. Абдурахманова Ф $К$. Функциональная транспозиция и омонимия в современном русском языке (на материале существительных и наречий): Автореф. дис. ... канд. филол. наук. Тверь, 1992.

27. Ардентов Б.П. «Что» в современном русском языке. Кишинев: Штиинца, 1973.

28. Жирикова О.А. О переходности местоимений // Русский язык в школе. 1957. по 2. C. $27-29$.

29. Ким О.М., Островская И.Е. Словарь грамматических омонимов русского языка. М.: Астрель, АСТ, Ермак, 2004.

30. Морковкин В.В., Луикая Н.М., Богачёва Г.Ф. и др. Объяснительный словарь русского языка: структурные слова: предлоги, союзы, частицы, местоимения, числительные, связочные глаголы: около 1200 единиц / под ред. В.В. Морковкина. М.: Астрель, АСТ, 2003.

31. Степанова О.Ю. Есть ли наречие что в современном русском языке? // Русский язык в школе. 2008. nо 9. С. $78-81$.

32. Шелякин M.A. Русские местоимения (значение, грамматические формы, употребление). Материалы к спецкурсу «Функциональная грамматика русского языка». Тарту, 1986.

33. Толковый словарь русского языка / под ред. Д.Н. Ушакова: В 4 т. М.: ОГИЗ, 19351940 // [Электронный ресурс]. Режим доступа: http://rus-yaz.niv.ru/doc/dictionaryushakov/articles/44/tot.htm. (дата обращения 20.03.2020.)

34. Ефремова Т.Ф. Толковый словарь русского языка. М.: Городец, 2009. [Электронный pecypc]. Режим доступа: https://gufo.me/dict/efremova/\%D1\%87\%D1\%82\%D0\%BE. (дата обращения 20.03.2020).

35. Ерёмин А.Н. Местоимения в просторечии (семантика и формальные особенности). Калуга: КГПУ имени К.Э. Циолковского, 1997.

36. Сыромятников Н.А. Классический японский язык / отв. ред. И.Ф. Вардуль. М.: ЛЕНАНД, 2014.

37. Фасмер М. Этимологический словарь русского языка: В 4 т. М.: Астрель : АСТ, 2007. [Электронный ресурс]. Режим доступа: https://glosum.ru/\%D0\%97\%D0\%BD\%D0\%B0\% D1\%87\%D0\%B5\%D0\%BD\%DB8\%D0\%B5-\%D1\%81\%D0\%BB\%D0\%BE\%D0\%B2\%D0\% B0-\% D0\%A7\%D1\%82 \% D0\%BE. (дата обращения 20.03.2020).

38. Шанский Н.М., Боброва Т.А. Школьный этимологический словарь русского языка. Происхождение слов. М.: Дрофа, 2004. [Электронный ресурс]. Режим доступа: http://www.slovorod.ru/etym-shansky/shan-ko.htm\#ko (дата обращения 20.03.2020).

39. Кузьлина C.M. Семантика и стилистика неопределённых местоимений // Грамматические исследования. Функционально-стилистический аспект. Суперсигментная фонетика. Морфологическая семантика. М.: Наука, 1989.

40. Пешковский A.M. Русский синтаксис в научном освещении. М.: Учпедгиз, 1956.

41. Сидоренко Е.Н. Семантические разряды местоимений современного русского языка // Русские местоимения: Семантика и грамматика. Межвуз. сб. науч. тр. Владимир: ВГПИ имени П.И. Лебедева-Полянского, 1989. С. 18-26.

42. Третьякова О.Д. Неопределённые местоимения, лишённые маркёра неопределённости, в типологической перспективе: автореф. дис. ... канд. филол. наук. М., 2009.

43. Труфанова И.В. Неопределённое местоимение какой // Экология языка: сб. науч. тр. / под ред. Е.Н. Сердобинцевой. Пенза: ПГУ, 2016. Вып. ІХ. С. 18-23.

44. Труфанова И.В. К каким лексико-грамматическим разрядам относится местоимение который? // Филологическая наука и школа: Диалог и сотрудничество: сб. тр. по мате- 
риалам VIII Междунар. науч.-практ. конф. / отв. ред. Л.В. Дудова. М.: Флинта: Наука, 2016. C. $18-28$.

45. Труфанова И.В. Определительные местоимения, обойдённые грамматиками // Язык и мышление: Психологические и лингвистические аспекты: Материалы XVIII-й Междунар. науч. конф. (Орехово-Зуево, 16-18 мая 2018 г.) / Отв. ред. проф. А.В. Пузырёв. М.: Ин-т языкознания РАН; Орехово-Зуево: ГОУ ВО МО «Государственный гуманитарнотехнологический университет», ФГНУ «Психологический институт» Российской академии образования, 2018. С. 66-76.

46. Ожегов С.И., Шведова Н.Ю. Толковый словарь русского языка. М.: Азбуковник, 1999. [Электронный ресурс]. Режим доступа: https://gufo.me/dict/ozhegov/\%D1\%87\%D1\%82\% D0\%BE. (дата обращения 20.03.2020).

47. Даль В.И. Толковый словарь живого великорусского языка: В 4 т. М.: Прогресс, 1994. [Электронный ресурс]. Режим доступа: https://gufo.me/dict/dal/\%D1\%87\%D1\%82\%D0\%BE. (дата обращения 20.03.2020).

48. Кузнецов С.А. Большой современный толковый словарь русского языка. СПб.: Норинт, 1998. [Электронный ресурс]. Режим доступа: https://gufo.me/dict/kuznetsov. (дата обращения 20.03.2020).

49. Словарь русского языка / под ред. А.П. Евгеньевой: В 4 т. М.: Наука, 1985-1988. [Электронный ресурс]. Режим доступа: https://gufo.me/dict/mas/\%D1\%87\%D1\%82\%D0\%BE. (дата обращения 20.03.2020).

50. Частотный словарь русского языка / под ред. Л.Н. Засориной. М.: Русский язык, 1977.

51. Zipf K. The meaning-frequency relationship of words // Journal of General Psychology. 1945. 33(2). P. 251-256.

52. Русская грамматика: В 2 т. Т. 2. М.: Наука, 1080. С. 392-393.

53. Колесникова С.М. Русские частицы: семантика, грамматика, функции. М.: Флинта; Наука, 2014.

54. Адмони В.Г. Типология предложения // Исследования по общей теории грамматики. М.: Наука. 1968. С. 232-292.

55. Золотова Г.А. Синтаксический словарь. Репертуар элементарных единиц русского синтаксиса / Отв. ред. Ю.Н. Караулов. М.: Наука, 1988.

56. Клобуков Е.Г. Семантика падежных форм в современном русском литературном языке (Введение в методику позиционного анализа). М.: Изд-во МГУ, 1986.

57. Энциклопедический словарь-справочник. Выразительные средства русского языка и речевые ошибки и недочёты / под ред. А.П. Сковордникова. М.: Флинта; Наука, 2006.

58. Лекант П.А. Синтаксис простого предложения в современном русском языке: Учеб. пособие. М.: Высш. шк., 2004.

59. Маркелова T.B. Грамматическая и семантическая структура односоставных негативных предложений с бытийным значением: автореф. дис. ... канд. филол. наук. М., 1982.

60. Жуковская Г.А. Генитивные конструкции в современном русском языке: автореф. дис. ... канд. филол. наук. Великий Новгород, 2005.

61. Монина Т.С. Проблема тождества предложения: автореф. дис. ... д-ра филол. наук. М., 1997.

62. Проничев В.П. Именные односоставные предложения в русском литературном языке в сопоставлении с сербскохорватским: автореф. дис. ... д-ра филол. наук. Л., 1991.

63. Галкина-Федорук Е.М. Безличные предложения в современном русском языке. М.: МГУ, 1958.

64. Бабайцева В.В. Односоставные предложения в современном русском языке. М.: Дрофа, 2004.

65. Валгина Н.С. Современный русский язык: Синтаксис. М.: Высш. шк., 2003.

66. Петров А.B. Безлично-генитивные предложения // Русский язык в шк. 2005. по 6. C. $78-81$. 
67. Локтев E.В. Безлично-генитивные предложения в современном русском языке: автореф. дис. ... канд. филол. наук. Архангельск, 2017.

68. Арутюнова Н.Д. Предложение и его смысл. Логико-семантические проблемы. М.: URSS, 2009.

\section{References}

1. Otkupshchikova, M.I. (1984). The pronouns of the modern Russian language in the structuralsemantic aspect. Leningrad: Publishing House of the Leningrad University. (In Russ.).

2. Akhmanova, O.S. (1957). Essays on general and Russian lexicology. Moscow: Uchpedgiz. (In Russ.).

3. Malakhovsky L.V. (2009). The theory of lexical and grammatical homonymy. Moscow: LIBROCOM. (In Russ.).

4. Kim, O.M. (1978). Transposition at the level of parts of speech and the phenomenon of homonymy in modern Russian. Tashkent: Fan. (In Russ.).

5. Kachurin, D.V. (2014). The problem of distinguishing homonymy and polysemy in relation to the practice of compiling explanatory dictionaries [dissertation]. Moscow. (In Russ.).

6. Novikov, L.A. (1982). Semantics of the Russian language. Moscow: Vysshaja shkola. (In Russ.).

7. Vysotskaya, I.V. (2006). Syncretism in the system of speech parts of the modern Russian language [dissertation]. Moscow. (In Russ.).

8. Babaitseva, V.V. (2016). The pronoun IT and its functional homonyms. Moscow: Flinta: Nauka. (In Russ.).

9. Bogdanova, M.A. (2014). The form, semantics, and functions of a token are good [dissertation]. Moscow. (In Russ.).

10. Emtseva, O.V. (2010). Words more and less in modern Russian [dissertation]. Moscow. (In Russ.).

11. Zhukova, T.A. (2003). The multifunctional lexical unit "by the word" and its contextfunctional synonyms [dissertation]. Vladivostok. (In Russ.).

12. Ilyina, A.B. (2005). "Hybrid" words with degree semantics in modern Russian (adverbsparticles) [dissertation]. Moscow. (In Russ.).

13. Kirichenko, I.V. (2002). Semantic and functional features of the word SIMPLY in modern Russian language [dissertation]. Stavropol. (In Russ.).

14. Lyulina, E.A. (2006). The word as in Russian (semantics, morphological and syntactic characteristics, functioning in the style varieties of the language) [dissertation]. Nizhny Novgorod. (In Russ.).

15. Milovanova, M.S. (2004). Functional homonyms of sound complexes against / opposite and their grammatical status [dissertation]. Moscow. (In Russ.).

16. Morgunova, A.N. (2016). The existence of the omocomplex is in the Russian discourse [dissertation]. Samara. (In Russ.).

17. Nikitina, O.V. (2008). Semantic and functional features of the word "directly" in modern Russian [dissertation]. Maykop. (In Russ.).

18. Semenova, O.V. (2000). Morphological status and syntactic functions of words like [dissertation]. Moscow. (In Russ.).

19. Sorokina, M.A. (2002). Functioning of the Homocomplex is True in modern Russian: [dissertation]. Moscow. (In Russ.).

20. Shamshin, Yu.N. (2007). The functioning of homocomplexes is many and few in modern Russian [dissertation]. Moscow. (In Russ.).

21. Babaitseva, V.V. (2000). The phenomena of transition in the grammar of the Russian language. Moscow: Drofa. (In Russ.).

22. Sidorenko, E.N. (1990). Essays on the theory of pronouns of the modern Russian language. Kiev, Odessa: Swan. 
23. Sidorenko, E.N. (2017). Morphology of the modern Russian language. Parts of speech and contaminants: a training manual. Moscow: Flinta; Nauka. (In Russ.).

24. Sternina, M.A. (2000). Lexico-grammatical polysemy in the language system (experience in developing the integral theory of polysemy) [dissertation]. Voronezh. (In Russ.).

25. Arsenyeva, M.G., Stroeva, T.V. \& Khazanovich, A.P. (1966). Ambiguity and homonymy. Leningrad: Leningrad State University. (In Russ.).

26. Abdurakhmanova, F.K. (1992). Functional transposition and homonymy in modern Russian (based on the material of nouns and adverbs) [dissertation]. Tver. (In Russ.).

27. Ardentov, B.P. (1973). "What” in modern Russian. Chisinau: Shtiintsa. (In Russ.).

28. Zhirikova, O.A. (1957). About transitive pronouns. Russian language at school, 2, 27-29. (In Russ.).

29. Kim, O.M. \& Ostrovskaya, I.E. (2004). Dictionary of grammatical homonyms of the Russian language. Moscow: Astrel, AST, Ermak. (In Russ.).

30. Morkovkin, V.V., Lutskaya, N.M., Bogacheva, G.F. \& al. (2003). Explanatory dictionary of the Russian language: structural words: prepositions, conjunctions, particles, pronouns, numerals, connected verbs: about 1200 units, V.V. Morkovkin (ed.). Moscow: Astrel; AST. (In Russ.).

31. Stepanova, O.Yu. (2008). Is there an adverb in modern Russian? Russian language at school, 9, 78-81. (In Russ.).

32. Shelyakin, M.A. (1986). Russian pronouns (meaning, grammatical forms, use) In Materials for the special course "Functional grammar of the Russian language." Tartu. (In Russ.).

33. Explanatory Dictionary of the Russian Language, D.N. Ushakov (Ed.): In 4 vols. Moscow: OGIZ, 1935-1940. [Electronic resource]. URL: http://rus-yaz.niv.ru/doc/dictionaryushakov/articles/44/tot.htm. (accessed: 10.03.2020). (In Russ.).

34. Efremova, T.F. (2009). Explanatory dictionary of the Russian language. Moscow: Gorodets. [Electronic resource]. URL: https://gufo.me/dict/efremova/\%D1\%87\%D1\%82\%D0\%BE. (accessed: 10.03.2020). (In Russ.).

35. Eremin, A.N. (1997). Colloquial pronouns (semantics and formal features). Kaluga: Kaluga State Pedagogical University named after K.E. Tsiolkovsky. (In Russ.).

36. Syromyatnikov, N.A. (2014). Classic Japanese. Moscow: LENAND. (In Russ.).

37. Fasmer, M. (2007). Etymological Dictionary of the Russian Language: In 4 vols. Moscow: Astrel: AST. [Electronic resource]. URL: https://glosum.ru/\%D0\%97\%D0\%BD\%D0\% B0\% D1\% 87\% D0\% B5\% D0\% BD\% DB8\% D0\% B5-\% D1\% 81\% D0\% BB\% D0\% BE\% D0\% B2\% D0\% B0-\% D0\% A7\% D1\% 82\% D0\% BE. (accessed: 10.03.2020). (In Russ.).

38. Shansky, N.M. \& Bobrova, T.A. (2004). School etymological dictionary of the Russian language. The origin of the words. Moscow: Drofa. [Electronic resource] URL: http://www.slovorod.ru/etym-shansky/shan-ko.htm\#ko. (accessed: 10.03.2020). (In Russ.).

39. Kuzmina, S.M. (1989). Semantics and stylistics of indefinite pronouns In Grammatical studies. Functional and stylistic aspect. Super-Segmental Phonetics. Morphological semantics. Moscow: Nauka. (In Russ.).

40. Peshkovsky, A.M. (1956). Russian syntax in scientific coverage. Moscow: Uchpedgiz. (In Russ.).

41. Sidorenko, E.N. (1989). Semantic categories of pronouns of the modern Russian language In Russian pronouns: Semantics and grammar. Interuniversity collection of scientific papers. Vladimir: Vladimir State Pedagogical Institute named after P.I. Lebedev-Polyansky. (In Russ.).

42. Tretyakova, O.D. (2009). Indefinite pronouns, lacking a marker of uncertainty, in a typological perspective [dissertation]. Moscow. (In Russ.).

43. Trufanova, I.V. (2016). What indefinite pronoun In Ecology of language: collection of scientific works, E.N. Serdobintseva (ed.). Issue IX. Penza: PSU. pp. 18-23. (In Russ.). 
44. Trufanova, I.V. (2016). What lexico-grammatical categories does the pronoun belong to? In Philology and school: Dialogue and cooperation: a collection of works on the materials of the VIII International scientific and practical conference, L.V. Dudova (ed.). Moscow: Flinta: Nauka. pp. 18-28. (In Russ.).

45. Trufanova, I.V. (2018). Definitive pronouns bypassed by grammars In Language and Thinking: Psychological and Linguistic Aspects: Materials of the XVIII International Scientific Conference (Orekhovo-Zuevo, May 16-18, 2018), A.V. Puzyryov (ed.). Moscow: Institute of Linguistics, RAS; Orekhovo-Zuyevo: GOU VO MO "State Humanitarian Technological University", FGNU "Psychological Institute" of the Russian Academy of Education. pp. 6676. (In Russ.).

46. Ozhegov, S.I. \& Shvedova, N.Yu. (1999). Explanatory dictionary of the Russian language. Moscow: Azbukovnik. [Electronic resource]. URL: https://gufo.me/dict/ozhegov/\% D1\%87\%D1\%82\% D0\% BE. (accessed: 10.03.2020).

47. Dal, V.I. (1994). Explanatory Dictionary of the Living Great Russian Language: in 4 vols. Moscow: Progress. [Electronic resource] URL: https://gufo.me/dict/dal/\%D1\%87\%D1\%82\% D0\%BE. (accessed: 10.03.2020). (In Russ.).

48. Kuznetsov, S.A. (1998). Large modern explanatory dictionary of the Russian language. St. Petersburg: Norint. [Electronic resource]. URL: https://gufo.me/dict/kuznetsov. (accessed: 10.03.2020). (In Russ.).

49. Dictionary of the Russian language (1985-1988). A.P. Evgenyeva (ed.): In 4 volumes. Moscow: Nauka. [Electronic resource]. URL: https://gufo.me/dict/mas/\%D1\%87\%D1\% 82\%D0\%BE. (accessed: 10.03.2020). (In Russ.).

50. The frequency dictionary of the Russian language (1977). L.N. Zasorina (ed.). Moscow: Russian language. (In Russ.).

51. Zipf, K. (1945). The meaning-frequency relationship of words. Journal of General Psychology, 33(2), 251-256.

52. Russian grammar: in 2 vols (1980). Vol. 2. Moscow: Nauka. (In Russ.).

53. Kolesnikova, S.M. (2014). Russian particles: semantics, grammar, functions. Moscow: Flinta; Nauka. (In Russ.).

54. Admoni,V.G. (1968). Typology of sentences In Studies in the general theory of grammar. Moscow: Nauka. pp. 232-292. (In Russ.).

55. Zolotova, G.A. (1988). Syntax Dictionary. Repertoire of elementary units of Russian syntax, Yu.N. Karaulov (ed.). Moscow: Nauka. (In Russ.).

56. Klobukov, E.G. (1986). The semantics of case forms in modern Russian literary language (Introduction to the methodology of positional analysis). Moscow: Moscow State University Publishing House. (In Russ.).

57. Encyclopedic reference dictionary Expressive means of the Russian language and speech errors and shortcomings (2006). A.P. Skovordnikov (ed.). Moscow: Flinta; Nauka. (In Russ.).

58. Lekant, P.A. (2004). Simple sentence syntax in modern Russian: a training manual. Moscow: Vysshaja shkola. (In Russ.).

59. Markelova, T.V. (1982). The grammatical and semantic structure of one-part negative sentences with existential meaning [dissertation]. Moscow. (In Russ.).

60. Zhukovskaya, G.A. (2005). Genitive constructions in modern Russian [dissertation]. Velikiy Novgorod. (In Russ.).

61. Monina, T.S. (1997). The problem of identity sentences [dissertation]. Moscow. (In Russ.).

62. Pronichev, V.P. (1991). Nominal single-compound sentences in the Russian literary language in comparison with the Serbo-Croatian [dissertation]. Leningrad. (In Russ.).

63. Galkina-Fedoruk, E.M. (2012). Impersonal sentences in modern Russian. Moscow. (In Russ.).

64. Babaitseva, V.V. (2004). Single-component sentences in modern Russian. Moscow: Drofa. (In Russ.).

65. Valgina, N.S. (2003). Modern Russian: Syntax. Moscow. (In Russ.). 
66. Petrov, A.V. (2005). Impersonal-genitive sentences. Russian language in school, 6, 78-81. (In Russ.).

67. Loktev, E.V. (2017). Impersonal-genitive sentences in modern Russian [dissertation]. Arkhangelsk. (In Russ.).

68. Arutyunova, N.D. (2009). Offer and its meaning. Logical and semantic problems. Moscow: URSS. (In Russ.).

\section{Information about the author:}

Trufanova Irina Vladimirovna, Doctor of Philology, Associate Professor, associate professor, teacher of additional education of the State budgetary educational institution of the city of Moscow "School No. 224"; Scientific interests: theoretical grammar, theory of speech acts, sociolinguistics, narratology; e-mail: illokucia1@ rambler.ru

\section{Сведения об авторе:}

Труфанова Ирина Владимировна, доктор филологических наук, доцент, педагог дополнительного образования Государственного бюджетного общеобразовательного учреждения города Москвы «Школа № 224»; научные интересы: теоретическая грамматика, теория речевых актов, социолингвистика, нарратология; e-mail: illokucia1@ rambler.ru. 